Int. J. Dev. Biol. 53: 291-301 (2009)

doi: $10.1387 / \mathrm{ijdb} .082698 \mathrm{~mm}$

\title{
Class Ila histone deacetylases: conducting development and differentiation
}

\author{
MAUD MARTIN, RICHARD KETTMANN and FRANCK DEQUIEDT* \\ Cellular and Molecular Biology Unit, FUSAGx, Gembloux, Belgium
}

\begin{abstract}
The emergence of specialized cell types and their organisation into organs and tissues involve the temporal modulation of many genes that are essential for coordinating the correct timing of instructive signals. These transcriptional changes are orchestrated with a precision that reminds that of a classical symphony. Extracellular signals are transmitted to key "integrators", which then orchestrate activation or repression of specific genes. In the last decade, class Ila HDACs have emerged as crucial regulators in various developmental and differentiation processes. This review focuses on the latest studies that have provided new insights into the biological functions of class Ila HDACs and discusses important aspects of their regulation. Elucidating cellular and molecular mechanisms by which functions of class Ila HDACs are modulated could potentially lead to new therapeutic opportunities for various diseases.
\end{abstract}

KEY WORDS: DAC, nucleocytoplasmic shuttling, acetylation, chromatin, MEF2

The classification of the eighteen human Histone Deacetylases (HDACs) identified to date relies on biochemical, structural and phylogenetic criteria. Based on their dependence on specific cofactors, a first division separates group I HDACs, which are zincdependent amidohydrolases, from group II enzymes (also known as class III HDACs or SIRTs), which rely on nicotinamide adenine dinucleotide (NAD) for their catalytic activity (Haigis and Guarente, 2006). Group I HDACs are further subdivided into classes I, II and IV, based on their similarity to yeast proteins (Yang and Seto, 2008). While class I HDACs (HDAC1,-2,-3 and -8) are related to the yeast transcriptional regulator Rpd3 (Rundlett et al., 1996; Taunton et al., 1996), class II enzymes (HDAC4,-5,-6,-7,-9,-10) show more similarity to yHDA1, a Rpd3-paralog (Fischer et al., 2002; Fischle et al., 2001; Fischle et al., 1999; Grozinger et al., 1999; Guardiola and Yao, 2002; Kao et al., 2000; Miska et al., 1999; Petrie et al., 2003; Tong et al., 2002; Verdel and Khochbin, 1999; Wang et al., 1999; Zhou et al., 2001; Zhou et al., 2000a). Careful phylogenetic analyses have singled HDAC11 out from other group I HDACs and led to the idea that it might be the defining member of a separate fourth class (Gregoretti et al., 2004).

Based on their structure, class II HDACs are further divided into two subclasses: class Ila (HDAC4, -5, -7 and -9) and class IIb (HDAC6 and -10) (Verdin et al., 2003). Class lla HDACs are the subject of this review and show a very specific structural organi- zation, that includes two distinct domains. The catalytic HDAC domain lies within the C-terminal half of the protein and corresponds to the HDA1-like sequences. The $\mathrm{N}$-terminal part of class Ila HDACs is the hallmark of the subfamily and contains specific conserved amino acid motifs that are specialized for binding an array of proteins, such as DNA-binding transcription factors, transcriptional corepressors and chaperone proteins (Martin et al., 2007). This adaptor domain of class Ila HDACs also contains several motifs specifically involved in their regulation. A canonical nuclear localization signal is found in the $\mathrm{N}$-terminus of all class Ila members and controls their subcellular localization (McKinsey et al., 2000a; McKinsey et al., 2001; Wang and Yang, 2001). In addition, several conserved residues are targeted by various post-translational modifications, such as ubiquitination (Li et al., 2004), sumoylation (Kirsh et al., 2002; Petrie et al., 2003), phosphorylation (Grozinger and Schreiber, 2000; Wang et al., 2000) and proteolytic cleavage (Bakin and Jung, 2004; Li et al., 2004; Paroni et al., 2004; Scott et al., 2008).

According to the current view, class lla HDACs are thought to act as transcriptional co-repressors by deacetylating nucleoso-

\footnotetext{
Abbreviations used in this paper: CAMK, Ca2+/calmodulin-dependent kinase; HDAC, histone deacetylase; MEF, myocyte enhancer factor; NAD, nicotinamide adenine dinucleotide; $\mathrm{PKD}$, protein kinase $\mathrm{D}$.
}

\footnotetext{
*Address correspondence to: Dr. Franck Dequiedt. Cellular and Molecular Biology Unit, 13, Av Marechal Juin, Bat 92,5030 Gembloux, Belgium. Fax: +32-81-613-888. e-mail: dequiedt.f@fsagx.ac.be

Published online: 24 April 2009.
}

ISSN: Online 1696-3547, Print 0214-6282 
mal histones in the vicinity of target promoters. Since class Ila HDACs do not bind to DNA, their repressive activity relies on interactions with sequence-specific DNA binding proteins, which thus dictate the targeting specificity of class Ila HDACs. The canonical example of this model is illustrated by the interaction between class Ila HDACs and myocyte enhancer factor 2 (MEF2) transcription factors (Martin et al., 2007). However, this simplistic model is challenged by a series of experimental evidence. It is notorious that compared to class I or class IIb, class Ila HDACs are very inefficient histone deacetylases (Fischle et al., 2002; Fischle et al., 1999; Hassig et al., 1998; Hu et al., 2000). An explanation for this intrinsic weak HDAC activity came from a recent study showing that, in place of a catalytic tyrosine residue that is strictly conserved in other group I enzymes, class Ila HDACs have an histidine that compromises their activity towards acetyl-lysines (Lahm, 2007). Very importantly, these findings raise the intriguing possibility that class Ila HDACs might in fact not target acetylated proteins, but still-to-be-discovered substrates. In addition, class Ila HDACs can repress transcription independently of their C-terminal catalytic domain, which suggests that at least part of their repressive properties does not rely on deacetylation of proximal histones (Kao et al., 2000; Lemercier et al., 2000; Sparrow et al., 1999; Wang et al., 1999; Zhou et al., 2000a). Indeed, the isolated N-terminal region of class Ila HDACs can repress transcription by recruiting co-repressors, such as HP1 or CtBP (Zhang et al., 2002; Zhang et al., 2001a; Zhang et al., 2001b). Finally, class Ila HDACs can also modulate the transcriptional activity of their partners by regulating specific posttranscriptional modifications, such as sumoylation (Gregoire et al., 2006; Gregoire and Yang, 2005; Zhao et al., 2005) or ubiquitination (Jeon et al., 2006; Jin et al., 2004).

In addition to their similar structural organization, class Ila HDACs also share the same overall mechanism of regulation. Regulation of class Ila members relies on their ability to shuttle between the nucleus and the cytoplasm, in response to specific extracellular signals (Martin et al., 2007). When in the nucleus, class Ila HDACs can partner with transcription factors and corepressors to inhibit transcription. In contrast, cytoplasmic accumulation of class Ila HDACs makes them unable to impact on transcription as it sequesters them away from histones and renders them enzymatically inactive as histone deacetylases (Fischle et al., 2001; Fischle et al., 2002). Multiple lines of evidence suggest that class Ila HDAC subcellular localization relies on the phosphorylation of several conserved serine residues located in their adaptor domain. When phosphorylated, these residues are targeted for binding by 14-3-3 proteins, which promote CRM1-dependent nuclear export and /or cytoplasmic sequestration of class Ila HDACs (Grozinger and Schreiber, 2000; Kao et al., 2001; Liu et al., 2005; Wang et al., 2000). In contrast, mutation of the phosphorylatable residues into alanine generates shuttling deficient class Ila HDACs and abolishes the signal-responsiveness of their target genes (Dequiedt et al., 2003; Ha et al., 2008; McKinsey et al., 2000a; Miska et al., 2001; Wang et al., 2008; Zhang et al., 2002; Zhang et al., 2001b). As described for several of their target proteins, 14-3-3 are thought to directly control the subcellular localization of class Ila HDACs by modulating the function of their NES and NLS (Grozinger and Schreiber, 2000; McKinsey et al., 2000a; Muslin and Xing, 2000). However, a series of important observations have been over- looked that are not compatible with this model. First, despite having intact 14-3-3 binding sites, HDAC5 mutants harboring inactivating mutations in their NES remain nuclear. But most importantly, the constitutive nuclear localization of these NES mutants does not increase their repressive activity. This indicates that release from their targeting DNA-binding partners, rather than exit from the nucleus is the crucial step in the relief of class Ila HDAC transcriptional repression by phosphorylation (Lu et al., 2000a; McKinsey et al., 2000a). In this context, 14-3-3-dependent nuclear export of class Ila HDACs may only serve as a supporting mechanism that ensures maximal activation of their target genes (McKinsey et al., 2000a). In addition, some data suggest that association with 14-3-3 could be dispensable for CRM1-mediated nuclear export of class Ila HDACs (Gao et al., 2006). Full comprehension of the complex mechanisms governing class Ila HDAC subcellular localisation and activity undoubtedly requires further investigation in order to solve these important issues.

As described above, inhibition of class Ila HDAC phosphorylation by serine-to-alanine mutation of the 14-3-3 consensus sites, leads to nuclear accumulation and increased repressive activity. This suggests that modulation of class Ila HDAC phosphorylation would provide the unique opportunity to control their biological functions. Indeed, activation of class Ila HDAC target genes can be achieved by overexpression of protein kinases or inhibition of protein phosphatase, each leading to hyperphosphorylation and cytoplasmic accumulation of class Ila HDACs. A great deal of effort has thus been invested in identifying the protein kinases and phosphatases targeting class IIa HDAC 14-3-3 motifs. To date, four families of serine/threonine kinases and two families of phosphatases have been implicated in this mechanism. Historically, members of the $\mathrm{Ca}^{2+} /$ calmodulin-dependent kinase family (CaMK), specifically CaMKI and IV, were the first kinases shown to promote 14-3-3 binding and nuclear export of class Ila HDACs. Functional relevance of these findings was provided in various biological contexts in which activation of CaMK members correlates with activation of class Ila HDAC targets genes (Backs et al., 2006; Bossuyt et al., 2008; Chawla et al., 2003; Davis et al., 2003; Grozinger and Schreiber, 2000; Kao et al., 2001; Karamboulas et al., 2006b; Linseman et al., 2003; Lu et al., 2000b; McKinsey et al., $2000 b)$. However, these studies mainly rely on overexpression or pharmacological inhibition of CaMK and remain to be validated by more definite loss-of-function approaches. More recently, protein kinase $D$ (PKD), a downstream effector of PKC was shown to phosphorylate the 14-3-3 binding sites of class Ila HDACs and neutralize their repressive activity (Dequiedt et al., 2005; Matthews et al., 2006; Parra et al., 2005; Vega et al., 2004a). Convincing experimental evidence have demonstrated that PKD activation is necessary for inactivation of class Ila HDACs during T-cell apoptosis (Dequiedt et al., 2005; Parra et al., 2005), cardiac hypertrophy (Bossuyt et al., 2008; Vega et al., 2004a), B-cell receptor signaling (Matthews et al., 2006), skeletal and cardiac muscle remodeling (Fielitz et al., 2008; Kim et al., 2008a) and angiogenesis (Ha et al., 2008; Wang et al., 2008). Mice with reduced CREB activity develop muscular dystrophy because of increased expression of salt-inducible kinase 1 (SIK1). Interestingly these mice also exhibit hyperphosphorylation of HDAC5, suggesting that SIK1 could be a class Ila HDAC kinase. Indeed loss- and gain-of-function studies demonstrated that SIK1 phosphorylates the 14-3-3 binding sites of HDAC5, revealing an important CREB- 
SIK1-HDAC5-MEF2 axis in the regulation of the myogenic program (Berdeaux et al., 2007; Takemori et al., 2009). However, whether this pathway is also conserved in other MEF2-regulated programs remains totally unexplored. In addition to the signalregulated protein kinases described above, two members of the microtubule affinity-regulating kinase (MARK)/Par-1 family, which are usually considered as constitutively active kinases (Lizcano et al., 2004), were shown to directly phosphorylate and promote nuclear export of class Ila HDACs (Chang et al., 2005; Dequiedt et al., 2006). Unfortunately, despite strong biochemical data these studies lack supporting evidence to demonstrate the biological relevance of their findings.

Considering the reversible nature of protein phosphorylation, protein phosphatases should be as important as protein kinases in the regulation of class Ila HDACs. Indeed, Parra et al. recently reported dephosphorylation of HDAC7 by the myosin phosphatase complex, which contains PP1 $\beta$ and myosin phosphatase targeting subunit 1 (MYPT1) (Parra et al., 2007). In addition, results from our laboratory and others have revealed that another cellular phosphatase, PP2A, stably associates with and constitutively dephosphorylates class Ila HDACs in vivo (Martin et al., 2008; Paroni et al., 2008). Accordingly, PP2A participates in the regulation of class Ila HDAC subcellular localization and directly impacts on their biological functions (Illi et al., 2008; Martin et al., 2008; Paroni et al., 2008; Sucharov et al., 2006). The sequential and/or coordinated actions of these multiple protein kinases and phosphatases would constitute a tightly regulated mechanism allowing appropriate, rapid, and reversible expression of class Ila HDAC target genes in response to specific developmental signals.

In addition to phosphorylation of their 14-3-3 binding sites, class Ila HDACs are subject to additional posttranslational modifications: phosphorylation/dephosphorylation at serine residues distinct from the 14-3-3 binding sites (Deng et al., 2005; Paroni et al., 2008; Zhou et al., 2000b), sumoylation (Kirsh et al., 2002; Petrie et al., 2003; Tatham et al., 2001), ubiquitination (Hook et al., 2002) and caspase cleavage (Li et al., 2004; Paroni et al., 2004; Scott et al., 2008). For more details on how these modifications impact on localization, stability, repressive or catalytic activity of specific members of class Ila HDACs, we respectfully refer the reader to recently published reviews (Martin et al., 2007; Yang and Seto, 2008).

Recently, two additional mechanisms of class Ila HDACs regulation have been documented. First, HDAC4 was shown to oligomerize with HDAC5, and to a lesser extent with HDAC9. Interestingly, amongst the class Ila HDACs, HDAC4 is uniquely sensitive to CaMKII-mediated phosphorylation and nuclear export (Backs et al., 2006). Hetero-oligomerization with HDAC4 brings HDAC5 in close proximity of CaMKII, allowing its phosphorylation by the kinase and promoting its nuclear export (Backs et al., 2008). Whether this transphosphorylation mechanism also exists for other class Ila HDACs and as-yetunidentified specific kinases remains unknown. In addition, two studies recently reported that expression of HDAC4 is regulated at the post-transcriptional level by microRNAs (miRNA). During skeletal muscle differentiation, miR-1 promotes myogenesis by targeting HDAC4
(Chen et al., 2006). Similarly, miR140, a cartilage specific miRNA, can bind to HDAC4 mRNA and interfere with its translation (Tuddenham et al., 2006). Unfortunately, the biological relevance of these findings during bone development was not investigated. Nonetheless, these important studies opened a new line of investigation in the regulation of class Ila HDACs which deserves to be explored in the context of other class Ila HDACs-regulated developmental programs.

The existence of multiple regulatory pathways converging on class Ila HDACs emphasizes the importance of these enzymes in various biological processes. In the past 5 years, genetic inactivation studies in mice conducted by the Olson laboratory have been instrumental in elucidating the biological functions of these enzymes. These studies have revealed the key role of class Ila members in several important developmental and differentiation processes. Surprisingly, despite the large number of transcriptional regulators targeted by class Ila HDACs, most of their functions seem to involve the transcriptional repression of MEF2 transcription factors (Fig. 1). In the following sections, we will review the latest insights into the biological functions of these fascinating enzymes.

\section{Chondrocyte hypertrophy}

HDAC4-null mice die during the perinatal period due to severe growth retardations and numerous skeletal abnormalities that result from excessive hypertrophic chondrocyte differentiation and inadequate endochondral ossification (Vega et al., 2004b). This remarkable phenotype was originally attributed to the ability of HDAC4 to repress Runt-related transcription factor-2 (Runx2), a well-recognized positive regulator of chondrocyte hypertrophy

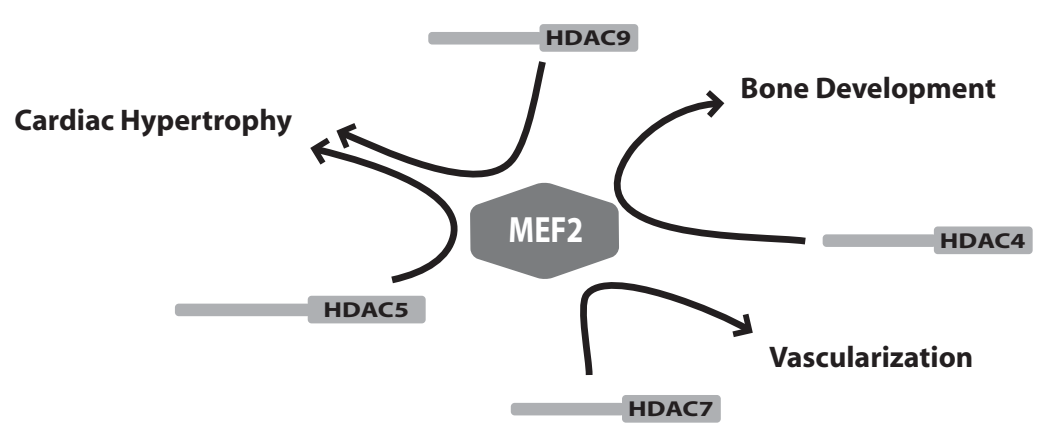

T-Cell Development

Neuron Survival

Fig. 1. Central role of MEF2 in the biological functions of class Ila HDACs. Gene targeting studies in mice have revealed tissue specific functions for each member of the class Ila HDACs. HDAC4-null mice display inappropriate chondrocyte hypertrophy whereas mice lacking HDAC7 die from cardiovascular defects and mutant mice for HDAC5 and HDAC9 develop spontaneous cardiac hypertrophy. Surprisingly, the known biological functions of class Ila HDACs have been associated with repression of the MEF2 family of transcription factors. A similar class Ila HDACsMEF2 axis could be involved in cardiac muscle development, skeletal muscle differentiation and remodelling and T-cell apoptosis. 
(Komori et al., 1997; Otto et al., 1997). Indeed, HDAC4 physically associates with Runx2 and inhibits its transcriptional activities. In addition, the phenotypic abnormalities of HDAC4 $\mathrm{KO}$ mice are strikingly reminiscent of those observed in mice with ectopic expression of Runx2 in prehypertrophic chondrocytes (Takeda et al., 2001; Ueta et al., 2001). The precise mechanism by which HDAC4 inhibits Runx2-mediated transcription remains obscure. Original observations suggested that repression of Runx 2 by HDAC4 might occur independently of its HDAC catalytic activity. Instead, HDAC4 was thought to impede on Runx2 DNA binding by direct association with its Runt domain (Vega et al., 2004b). However this model failed to explain why HDAC4 mutants consisting of the C-terminal catalytic domain of HDAC4, and thus lacking the Runx2 binding region, retain significant repressive activity. The recent observation that HDAC4 and HDAC5 deacetylate Runx2 and Runx3 provides an explanation for these apparent discrepancies (Jeon et al., 2006; Jin et al., 2004). In addition to preventing Runx2 from binding to DNA, HDAC4 may deacetylate Runx2 and promote its ubiquitin-mediated degradation. This double-targeting of Runx2 by HDAC4 would thus solely explain its key role as a negative regulator of chondrocyte hypertrophy.

This apparently satisfying model was recently challenged by a study published by the same authors and which unravelled the unexpected role of MEF2C in chondrocyte hypertrophy (Arnold et al., 2007). This study reports that homo- or even heterozygous mutation of Mef2c is associated with severe skeleton defects resulting from reduced chondrocyte hypertrophy and ossification of endochondral bones. Given the preponderance of the class Ila HDACs-MEF2 axis in several developmental programs (see below), this unexpected finding raises the possibility that bone defects associated with deletion of Hdac4 could, at least partly, result from hyperactivation of MEF2C. Supporting this hypothesis, a genetic antagonism exists between HDAC4 and MEF2: the excessive endochondral ossification observed in HDAC4 null mice is partially abolished by deletion of one Mef2c allele. Conversely, inactivation of Hdac4 in the presence of a heterozygous Mef2c allele partially restored normal endochondral ossification. Interestingly, expression of Runx2 was greatly diminished in the endochondral cartilage of Mef2c mutant mice, indicating that some of the defects associated with Mef2c deficiency may be mediated by reduced Runx2 activity. By controlling key transcriptional regulators of chondrocyte hypertrophy, it is thus clear that HDAC4 plays a central role in the control of bone development. Interestingly, Runx2 is involved at multiple stages of bone development, such as osteoblast differentiation (Komori, 2008). Using in vitro models, HDAC7 was recently identified as a negative regulator of osteoblast differentiation through its Runx2 corepressor function (Jensen et al., 2008). In addition, HDAC4 and HDAC5 have been shown to participate in the repression of Runx2 by Smad3 during osteoblast differentiation (Kang et al., 2005). While HDAC4 and -5 are expressed at significant levels in mesenchymal cells and osteoblasts, no evidence for HDAC7 expression in this cell lineage has been reported. In addition, the severe skeletal defects associated with HDAC4 deficiency were not observed in other class Ila HDACs mutant mice and could imply a specific role for HDAC4 as a negative regulator of bone development. A more careful examination of bone devel- opment in mice lacking class Ila HDACs should unravel any functional overlap that may exist between these proteins.

\section{Myogenesis}

\section{Skeletal muscle differentiation}

Formation of skeletal muscle involves commitment of multipotential mesodermal precursor cells to the muscle lineage and their proliferation as myoblasts. Upon mitogens withdrawal, proliferating myoblasts exit the cell cycle and differentiate into multinucleated muscle fibers. The myogenic process results from a specific genetic program, with activation of hundreds of muscle-specific genes and repression of genes associated with cell proliferation. MEF2 has long been known as a key transcriptional regulator of skeletal muscle differentiation. Logically, the functional association between MEF2 family members and class Ila HDACs was originally tested in the context of myogenesis (Wang et al., 1999; Miska et al., 1999; Lu et al., 2000a; Lemercier et al., 2000). In vitro, class Ila HDACs negatively regulate muscle differentiation through association with MEF2 and repression of its target genes (Dressel et al., 2001; Haberland et al., 2007; Lu et al., 2000b). In addition, the inhibitory action of class Ila HDACs can be overcome by myogenic signals that disrupt MEF2-HDAC interactions and stimulate nuclear export of these transcriptional repressors during muscle differentiation (McKinsey et al., 2002). Surprisingly, normal overall skeletal muscle differentiation was maintained in mice mutated in each individual class Ila HDAC. This apparent discrepancy might result from the partial functional overlap that may exist between class Ila HDAC members. However, several observations indicate that the functional redundancy observed between class Ila HDACs in vitro may not exist in vivo. Indeed, class Ila members show distinct subcellular localizations in muscle cells. HDAC4 is mainly cytoplasmic in undifferentiated myoblasts and accumulates in the nucleus upon differentiation into myotubes, (Miska et al., 2001). In contrast, HDAC5 and HDAC7 relocate from the nucleus to the cytoplasm as myoblasts differentiate into myotubes (Dressel et al., 2001; McKinsey et al., 2000a). These findings suggest that class Ila HDACs respond differently to physiologic stimuli and could thus have distinct roles during skeletal muscle differentiation.

\section{Skeletal muscle remodelling}

Skeletal muscle of adult vertebrates consists of type I and type II myofibers, which differ with respect to size, metabolism and contractile function. Slow-twitch or type I myofibers exhibit an oxidative metabolism and are resistant to fatigue, while in contrast, fast-twitch or type II fibers use glycolytic metabolism, fatigue rapidly and are involved in rapid bursts of activity. Numerous stimuli modulate skeletal muscle phenotype and induce switch from one specialized myofiber type to the other. MEF2 is preferentially activated in slow, oxidative myofibers (Wu et al., 2000) and activates the slow myofiber gene program (Potthoff et al., 2007). Logically, class Ila HDACs were recently implicated in the regulation of myofiber identity. In slow or oxidative fibers, class Ila HDACs are selectively degraded through a proteasome-dependent pathway. This specific degradation of class Ila HDACs alleviates their repression over MEF2, and probably other unidentified transcription factors allowing the induction of a slow skeletal muscle specific gene program. Mice lacking individual class Ila 
HDACs in their skeletal muscle did not display abnormalities in fiber-type switching. However deletion of any combination of 4 alleles of Hdac4, -5 , or -9 results in enhanced slow-fiber gene expression and increased percentage of slow myofibers, revealing functional redundancy between class Ila members. Interestingly, overexpression of constitutively active forms of PKD and CaMKIV, in adult glycolytic fibers of transgenic mice results in an increase in the number of slow fibers and enhances muscle oxidative capacity (Kim et al., 2008a; Wu et al., 2002). Because previous studies have established that these kinases stimulate MEF2 activity by promoting the phosphorylation and export of class II HDACs from the nucleus (Martin et al., 2007), these observations further support a role for class Ila HDACs in fiber type specification.

In response to variations in environmental and functional demands, skeletal muscle adapt by remodelling the biochemical, morphological, and physiological states of individual myofibers (Bassel-Duby and Olson, 2006). These changes involve activation of intracellular signalling pathways and consequent genetic reprogramming, resulting in alterations of muscle mass, contractile properties, and metabolic states. Numerous stimuli, such as exercise, electrical stimulation or microgravity can induce muscle remodelling. Neuron-induced electrical activity has been known for a long time to induce specific transcriptional reprogramming of muscle and several neural activity-responsive genes have been identified. A typical example is the nicotinic acetylcholine receptors (AChRs), whose expression is highly sensitive to muscle innervation. AChR expression relies on the basic helix-loop-helix (bHLH) myogenic transcription factor myogenin. After innervation, neuron-induced electrical activity induces active transcriptional repression of myogenin throughout the muscle, which coincides with decreased extra-synaptic AChR expression levels. Recently, class Ila HDACs have been directly implicated in the regulation of myogenin expression. In innervated muscle, MITR, the non catalytic isoform of HDAC9, is highly expressed and represses transcription of myogenin through inhibition of MEF2. Conversely, denervation induces dramatic transcriptional downregulation of MITR, which correlates with subsequent myogenin and AChR expression (Mejat et al., 2005). Interestingly, the observation that a MITR mutant protein lacking the MEF2-interacting domain retains $50 \%$ inhibitory activity on the expression of AChR and myogenin suggests that MITR could have additional targets besides MEF2. HDAC9-null mice do not show any obvious perturbation of skeletal muscle function under normal conditions but were sensitized to denervation. This sensitized phenotype is reminiscent of the cardiac phenotype observed in HDAC5 and HDAC9- null mice and establishes class Ila HDACs as general stress sensors and integrators.

Besides MEF2, Dash2, a Dachschund related transcriptional co-repressor whose expression is decreased upon denervation, was reported to inhibit myogenin expression in innervated muscle (Tang and Goldman, 2006). In contrast to MITR/HDAC9, HDAC4 expression is highly induced in response to denervation, suggesting that both class Ila HDACs could have opposite effects in denervation-induced nAChR expression (Cohen et al., 2007). This model is supported by the observation that neuronal input also induces nuclear accumulation of HDAC4 (Liu et al., 2005). In the nucleus, HDAC4 associates with the Dach2 promoter and thus activates the myogenin/AChR cascade through active down- regulation of Dach2. Unexpectedly, the opposite regulations of HDAC4 and MITR by neuronal activity lead to the same transcriptional outcome: induction of myogenin/AChR expression by denervation. The most interesting corollary to these observations is that these two class Ila members must impede on the neuronal activity-dependent transcriptional reprogramming of muscle through non-redundant, complementary pathways. Whether similar combinatorial regulation by multiple class Ila members also exists for other transcriptional programs involving class Ila HDACs needs to be investigated.

\section{Cardiac muscle development}

Heart formation is initiated from the mesoderm in vertebrate embryos. The first stage of cardiomyogenesis involves the formation of cardiomyoblasts, which express a distinct subset of transcription factors, including MEF2C, the homeobox transcription factor Nkx2-5 and members of the cardiac GATA subfamily (Zaffran and Frasch, 2002). These factors activate the expression of cardiac-muscle-specific genes to form the differentiated cardiomyocytes. Overexpression of HDAC4, or inhibition of the inactivating class Ila HDAC kinase CaMK, was shown to inhibits the transition from mesoderm to cardiomyoblast during cardiomyogenesis in P19 cells (Karamboulas et al., 2006b). Surprisingly, mice mutated for individual class Ila HDACs do not exhibit obvious abnormalities of the hearth. In contrast, HDAC5/ 9 double mutant mice are prone to perinatal death from ventricular septum defects and thin ventricular walls, which typically originate from abnormalities in growth and maturation of cardiomyocytes (Chang et al., 2004). Whereas the molecular mechanisms underlying the role of class Ila HDACs in these processes remain obscure, studies in mice and Drosophila have established the importance of MEF2 in the control of cardiac muscle differentiation (Bour et al., 1995; Karamboulas et al., 2006a; Lilly et al., 1995; Lin et al., 1997; Ranganayakulu et al., 1995). It is thus likely that at least part of the cardiomyogenesis defects associated with class Ila HDACs inactivation arise from superactivation of MEF2 transcriptional activity. However, it is also possible that class Ila HDACs directly or indirectly repress other transcription factors that are important for cardiomyogenesis, such as SRF, CAMTA, Nkx2-5, myocardin and GATA factors (Davis et al., 2003; Han et al., 2006; Long et al., 2007; Song et al., 2006).

\section{Cardiac hypertrophy}

Cardiac hypertrophy, which is defined as an increase in cardiomyocyte size and reactivation of a specific fetal cardiac gene program, is an adaptive response of the heart to a variety of stress stimuli. Stress-induced hypertrophy may initially normalize ventricular wall stress, but excessive hypertrophic growth of the heart frequently leads to maladaptive changes that ultimately weakens cardiac performance and can lead to heart failure (Backs and Olson, 2006; Hill and Olson, 2008).

Transcripts for every class Ila HDACs, including the splicing HDAC9 variant MITR are found at high levels in mouse heart (Zhang et al., 2002). In addition, ectopic expression of constitutively repressive mutants of HDAC4, -5 and -9 (i.e. mutants insensitive to signal-responsive class Ila HDAC kinases) suppress hypertrophy of primary cardiomyocytes and expression of fetal cardiac genes in vitro (Backs et al., 2006; Vega et al., 2004a; Zhang et al., 2002). Gene-inactivation studies in mice have 
provided definite evidence of the importance of class Ila HDACs as signal-responsive suppressors of postnatal cardiac growth. HDAC5 or HDAC9-KO mice exhibit no evidence of cardiac abnormalities during the early post-natal period. However, within their first year, these mutant mice develop spontaneous cardiac hypertrophy, which appears to result form hypersensitivity to agerelated cardiac stress. HDAC5 and HDAC9 mutant mice also show exacerbated hypertophic response to pressure overload or constitutive activation of calcineurin (Chang et al., 2004; Zhang et al., 2002). The remarkably similar cardiac phenotypes observed in HDAC5 or HDAC9 mutant mice suggest that these two class Ila members play redundant roles in the control of the same pathological hypertrophy signalling pathways. Unfortunately, mice lacking either HDAC4 or HDAC7 are not viable, which has precluded from investigating the potential involvement of these class IIa members in cardiac hypertrophy (Chang et al., 2006; Vega et al., 2004b). Conditional gene deletion studies will be needed to test whether HDAC4 and HDAC7 play functional roles similar to that of HDAC5 and HDAC9 in the cardiac pathologic response.

MEF2, and in particular MEF2D plays an important role as an integrator and mediator of stress-dependent remodelling of the adult heart (Kim et al., 2008b; Lu et al., 2000a; Nadruz et al., 2003). Indeed, Mefd2d-null mice display impaired cardiac hypertrophic response to pressure overload and adrenergic signalling (Kim et al., 2008b). Hypertrophic cardiac growth in HDAC5 or HDAC9 mutant mice correlates with superactivation of MEF2, suggesting that MEF2 is the critical target of class Ila HDACs in specific signalling pathways leading to cardiac hypertrophy. Indeed, while inactivation of Mef2d alleles renders mice resistant to cardiac remodelling in response to $\beta$-adrenergic stimulation, HDAC5 or HDAC9-null mice respond normally to isoproterenol stimulation (Chang et al., 2004; Kim et al., 2008b). This interesting observation could indicate that only specific signalling pathways of cardiac hypertophy involve class Ila HDAC-mediated regulation of MEF2. On the other hand, the insensitivity of mice lacking either HDAC5 or HDAC9 to adrenergic stimuli could suggest a functional redundancy with other class Ila members in this particular pathway. Identification of the precise role and specific physiological relevant targets of each class Ila HDAC in cardiac hypertrophy will help solving these important issues.

\section{Neuronal survival}

HDAC4 and HDAC5 mRNA are highly abundant in the brain suggesting a role for these class lla members in neurons (Grozinger et al., 1999). HDAC4 is predominantly cytoplasmic in cerebellar granule neurons (CGNs), and signals promoting its nuclear translocation or expression of constitutively nuclear mutants correlates with apoptosis (Bolger and Yao, 2005). Similarly, HDAC5 is mainly cytoplasmic in CGNs cultured under depolarizing conditions. Switching CGNs to non-depolarizing medium, which induces cytoplasm-to-nucleus translocation of HDAC4 and -5, correlates with induction of apoptosis (Linseman et al., 2003). MEF2 is a well-established survival factor in neurons (Mao et al., 1999) and as expected, induction of apoptosis by HDAC4 and -5 correlates with repression of MEF2 transcriptional activity (Bolger and Yao, 2005; Linseman et al., 2003). However, whether HDAC4 and/or HDAC5 target any other transcription factor besides MEF2 remains to be explored. Interestingly, HDAC4 appears to have a more predominant role in neuronal cell death, as siRNA-mediated inhibition of HDAC4 efficiently suppresses neuronal death, arguing against functional redundancy between HDAC4 and HDAC5 (Bolger and Yao, 2005). In addition, HDAC5 knockdown mice showed no obvious brain defects, whereas mice lacking HDAC4 have abnormal shaped brains and exencephaly, probably resulting form precocious ossification of the brain (Vega et al., 2004b). However, more careful examination of HDAC4-null mice revealed delay in the formation of folia, suggesting a pro-survival rather than a pro-apoptotic role for HDAC4 (Majdzadeh et al., 2008; Vega et al., 2004b). Indeed, a recent study reported that HDAC4 prevents low-potassium induced neuronal cell death, through inhibition of activity of cyclin-dependent kinase-1 (CDK1). Supporting their results, the authors described higher CDK1 activity in the brain of HDAC4-/- mice (Majdzadeh et al., 2008). Similarly, studies using a model of mouse retina degeneration showed that HDAC4 promotes survival of photoreceptor cells (Chen and Chepko, 2009). Interestingly, this pro-survival function of HDAC4 was associated with its presence in the cytoplasm and might thus be independent of its nuclear repressive function. The reasons for these contradictory results remain unclear and should instigate further studies about the role of class Ila HDACs in neurons.

\section{Immune cells}

After entering the thymus, precursor T-cells differentiate into mature lymphocytes following a complex and highly regulated process (Ciofani and Zuniga-Pflucker, 2007). Complete maturation of developing thymocytes implies that they successfully pass a series of developmental checkpoints. After complete rearrangement of their T-cell receptor (TCR) chains, thymocytes become $\mathrm{CD}^{+} / \mathrm{CD}^{+}$, or double-positive (DP) thymocytes and undergo negative and positive selection. During these processes, their TCR is tested for its ability to interact with selfpeptide bound to major histocompatibility complex (MHC) molecules of the thymic antigen-presenting cells (APCs). Positive selection will only allow further differentiation of thymocytes carrying a functional TCR. Potentially autoreactive thymocytes bearing TCR with strong affinity to $\mathrm{MHC}$-self peptide complexes are deleted by the apoptotic process of negative selection. The different developmental fates of maturing thymocytes are dictated by the integration of various signals and the translation of these signals into changes in gene expression.

In human, HDAC7 is highly expressed in thymus, heart and lung. Within the thymus, we have shown that HDAC7 is transiently and predominantly expressed in CD4/CD8 DP thymocytes (Dequiedt et al., 2003). Consistent with this, HDAC7 associates with MEF2D and represses the expression of a series of MEF2-target genes involved in negative and positive selections, such as the pro-apoptotic orphan nuclear receptor Nur77 (Dequiedt et al., 2003; Kasler and Verdin, 2007). The release of HDAC7-mediated repression is achieved through a complex signalling cascade. Engagement of the TCR by MHCself peptides results in dissociation of HDAC7-MEF2D complexes, phosphorylation and cytoplasmic accumulation of HDAC7 which ultimately leads to de-repression of MEF2-target genes (Dequiedt et al., 2005). Interestingly, microarray-based 
analysis has revealed that HDAC7 could regulate both MEF2dependent and independent genes (Kasler and Verdin, 2007). However, how HDAC7 regulates transcription independently of MEF2 was not investigated. Amongst the MEF2-HDAC7 regulated genes in thymocytes, this study also identified HDAC5, which could suggest a role for this class Ila member during $\mathrm{T}$ cell differentiation.

In B cells, signalling from the B-cell antigen receptor has been shown to regulate HDAC5 and HDAC7 phosphorylation, localization and repressive function (Matthews et al., 2006). Even if chemical inhibition of HDACs supports a role for HDACs in B-cell differentiation and survival, the transcriptional targets and functional significance of these findings remain currently unknown.

\section{Vascularisation}

Early studies using general HDAC inhibitors suggested the possible implication of zinc-dependent HDACs in the transcriptional control of endothelial gene expression and vascular development (Kim et al., 2001; Kwon et al., 2002). However, until recently, definite experimental evidence about the function of class I and class II HDACs in these processes was lacking.

In situ hybridization studies revealed specific expression of HDAC7 in the vascular endothelium during mouse embryogenesis. Consistent with this, inactivation of the HDAC7 gene in a ubiquitous or endothelial specific manner had dramatic consequences on vascular integrity, with mutant mice dying in utero from blood vessel dilatations, ruptures and haemorrhages. In addition, siRNA-mediated inactivation of HDAC7 in human umbilical vein endothelial cells (HUVECs) prevents formation of capillary-like structures in vitro(Chang et al., 2006). Microarray analysis revealed that HDAC7 regulates the expression of several genes encoding extracellular matrix and adhesion proteins, among which the secreted matrix metalloprotease 10 (MMP-10). Regulation of MMP-10 expression by HDAC7 relies on its association with MEF2C, a factor implicated in blood vessel development and vascular integrity (Lin et al., 1998), and constitutes yet another example in which the class IIa HDACs-MEF2 axis controls an important genetic developmental program. Inappropriate expression of MMP10 in HDAC7null mice would be expected to disrupt endothelial cell-cell adhesion and could thus explain the defects associated with HDAC7 inactivation. However, a more recent study has brought some new light on the role of HDAC7 during angiogenesis and vascularisation. Using a complete set of in vitro assays, Mottet and colleagues have shown that the inability of HDAC7-silenced HUVECs to assemble into tube-like structures in vitro could result from alterations of their motility (Mottet et al., 2007). In addition, HDAC7 silencing correlates with increased expression of PDGF-B, a regulator of migration and tubulogenesis of endothelial cells (De Marchis et al., 2002). Even though the molecular mechanisms underlying the transcriptional control of PDGF-B by HDAC7 are unknown, these findings raise the appealing possibility that HDAC7 might regulate multiple stages during vasculature formation. Interestingly, HDAC7 silencing was also associated with altered morphology of the cells, which could also impact on their angiogenic properties (Holderfield and Hughes, 2008). Considering its potential impact on multiple aspects of vasculogenesis, identification of HDAC7 target genes has become a necessary step toward a better understanding of vascular development.

\section{Future prospects}

As described above, the past 5 years have witnessed the emergence of class Ila HDACs as key regulators in several important biological processes. Through their signal-responsive regulation and their ability to repress the transcriptional activity of numerous transcription factors, class Ila HDACs integrate and translate extracellular signals into specific genetic activation programs. Recent studies in mice deficient for each class Ila member have corroborated this model and revealed major defects in important developmental programs such as embryonic bone formation and vascularisation and cardiac hypertrophy (see above). While groundbreaking, these studies have focused on the functions of class Ila HDACs leading to the most spectacular phenotypical defects. However, the early observation that class Ila HDACs are expressed in multiple tissues suggests that they might have several biological functions, depending on the cellular context. More careful examination of class Ila HDAC null-mice should identify less obvious phenotypical defects and therefore suggest additional biological functions for these enzymes. For instance, while HDAC4-deficient mice die perinatally from skeletal defects, demonstrating the key role of this class Ila member in bone development, they also exhibit cerebellar abnormalities which could support a role for HDAC4 in neuronal survival (Majdzadeh et al., 2008).

Surprisingly, and despite the fact that they can associate with a plethora of partners, the biological functions of class Ila HDACs seem to rely almost uniquely on their association with MEF2 transcription factors. MEF2 has been implicated in a myriad of developmental, physiological and pathological processes, each of which could potentially be regulated by a class Ila HDACsMEF2 axis. Amongst the MEF2-regulated processes, the unique or redundant in vivo functions of class lla members remain to be investigated in contractile myofibril assembly (Hinits and Hughes, 2007), craniofacial development (Verzi et al., 2007), postsynaptic morphogenesis and brain development (Shalizi et al., 2006; Shalizi and Bonni, 2005). Inversely, several lines of experimental evidence suggest that class Ila HDACs can regulate transcription independently of MEF2 (Kasler and Verdin, 2007). Nonetheless, whether MEF2-independent biological functions exist for class Ila HDACs remains an unanswered question and deserves to be thoroughly adressed. The existing studies about the in vivo functions of class Ila HDACs have overlooked the many other transcriptional targets of these enzymes and often linked the observed physiological defects with hyperactivation of MEF2. The existence of knock-out mice for each class lla HDAC member gives now the opportunity to validate additional known class Ila HDAC partners besides MEF2.

Functional inactivation of class Ila HDACs via signal-dependent phosphorylation and nuclear export has been extensively illustrated in in vitro systems (Martin et al., 2007). This mechanism is now being validated in vivo by recent studies showing the importance of known class Ila HDAC kinases in cardiac hypertrophy (Backs et al., 2006; Fielitz et al., 2008; Harrison et al., 2006) and skeletal muscle function and remodeling (Kim et al., 2008a). 
Logically, class Ila HDAC kinases should also be involved in other class Ila HDAC regulated genetic programs such as chondrocytes hypertrophy, neuron and immune cells apoptosis (Dequiedt et al., 2005; Parra et al., 2005), and blood vessel development (Harrison et al., 2006).

The establishment of class Ila HDACs as key modulators of various differentiation and developmental programs, especially in pathological related processes, potentially offers new therapeutic strategies for various human diseases. A still limited number of studies have reported alterations of class Ila HDACs in several cancers (Chaabouni et al., 2006; Ouaissi et al., 2008; Ozdag et al., 2006; Yuki et al., 2004) and neuronal disorders (Hoshino et al., 2003; Iga et al., 2007; Renthal et al., 2007). Armed with the new insights into their regulation and biological functions, it seems possible to specifically modulate class Ila HDAC activity and normalize pathological gene expression patterns in disorders such as cardiac hypertrophy, hearth failure, tumour growth or skeletal muscle wasting.

\section{Acknowledgements}

We apologize to those investigators whose work was not cited in this article owing to space limitations. This work was supported by the Belgian National Fund for Scientific Research (F.N.R.S) and the Interuniversity Attraction Poles Programme, Belgian Science Policy (PA/6/07). F.D. is Research Associate, M.M. is Research Fellow and R.K. is Research Director of the F.N.R.S.

\section{References}

ARNOLD, M.A., KIM, Y., CZUBRYT, M.P., PHAN, D., MCANALLY, J., QI, X., SHELTON, J.M., RICHARDSON, J.A., BASSEL-DUBY, R. and OLSON, E.N. (2007). Mef2c transcription factor controls chondrocyte hypertrophy and bone development. Dev Cell 12: 377-389.

BACKS, J., BACKS, T., BEZPROZVANNAYA, S., MCKINSEY, T.A. and OLSON, E.N. (2008). Histone deacetylase 5 acquires calcium/calmodulin-dependent kinase ii responsiveness by oligomerization with histone deacetylase 4. Mol Cell Biol 28: 3437-3445.

BACKS, J. and OLSON, E.N. (2006). Control of cardiac growth by histone acetylation/deacetylation, Circ Res 98: 15-24.

BACKS, J., SONG, K., BEZPROZVANNAYA, S., CHANG, S. and OLSON, E.N. (2006). Cam kinase ii selectively signals to histone deacetylase 4 during cardiomyocyte hypertrophy. J Clin Invest 116: 1853-1864.

BAKIN, R.E. and JUNG, M.O. (2004). Cytoplasmic sequestration of hdac7 from mitochondrial and nuclear compartments upon initiation of apoptosis. J Biol Chem 279: 51218-51225.

BASSEL-DUBY, R. and OLSON, E.N. (2006). Signaling pathways in skeletal muscle remodeling. Annu Rev Biochem 75: 19-37.

BERDEAUX, R., GOEBEL, N., BANASZYNSKI, L., TAKEMORI, H., WANDLESS, T., SHELTON, G.D. and MONTMINY, M. (2007). Sik1 is a class ii hdac kinase that promotes survival of skeletal myocytes. Nat Med 13: 597-603.

BOLGER, T.A. and YAO, T.P. (2005). Intracellular trafficking of histone deacetylase 4 regulates neuronal cell death. $J$ Neurosci 25: 9544-9553.

BOSSUYT, J., HELMSTADTER, K., WU, X., CLEMENTS-JEWERY, H., HAWORTH, R.S., AVKIRAN, M., MARTIN, J.L., POGWIZD, S.M. and BERS, D.M. (2008). $\mathrm{Ca2+/calmodulin-dependent} \mathrm{protein} \mathrm{kinase} \mathrm{iidelta} \mathrm{and} \mathrm{protein} \mathrm{kinase} \mathrm{d} \mathrm{overex-}$ pression reinforce the histone deacetylase 5 redistribution in heart failure. Circ Res 102: 695-702.

BOUR, B.A., O'BRIEN, M.A., LOCKWOOD, W.L., GOLDSTEIN, E.S., BODMER, R., TAGHERT, P.H., ABMAYR, S.M. and NGUYEN, H.T. (1995). Drosophila mef2, a transcription factor that is essential for myogenesis. Genes Dev 9: 730741.

CHAABOUNI, M., LE MERRER, M., RAOUL, O., PRIEUR, M., DE BLOIS, M.C., PHILIPPE, A., VEKEMANS, M. and ROMANA, S.P. (2006). Molecular cytoge- netic analysis of five $2 q 37$ deletions: Refining the brachydactyly candidate region. Eur J Med Genet 49: 255-263.

CHANG, S., BEZPROZVANNAYA, S., LI, S. and OLSON, E.N. (2005). An expression screen reveals modulators of class ii histone deacetylase phosphorylation. Proc Natl Acad Sci USA 102: 8120-8125.

CHANG, S., MCKINSEY, T.A., ZHANG, C.L., RICHARDSON, J.A., HILL, J.A. and OLSON, E.N. (2004). Histone deacetylases 5 and 9 govern responsiveness of the heart to a subset of stress signals and play redundant roles in heart development. Mol Cell Biol 24: 8467-8476.

CHANG, S., YOUNG, B.D., LI, S., QI, X., RICHARDSON, J.A. and OLSON, E.N. (2006). Histone deacetylase 7 maintains vascular integrity by repressing matrix metalloproteinase 10. Cell 126: 321-334.

CHAWLA, S., VANHOUTTE, P., ARNOLD, F.J., HUANG, C.L. and BADING, H. (2003). Neuronal activity-dependent nucleocytoplasmic shuttling of hdac4 and hdac5. J Neurochem 85: 151-159.

CHEN, J.F., MANDEL, E.M., THOMSON, J.M., WU, Q., CALLIS, T.E., HAMMOND, S.M., CONLON, F.L. and WANG, D.Z. (2006). The role of microrna-1 and microrna-133 in skeletal muscle proliferation and differentiation. Nat Genet 38: 228-233.

CHEN B. and CEPKO C.L. (2009). HDAC4 regulates neuronal survival in normal and diseased retinas. Science 323: 256-259.

CIOFANI, M. and ZUNIGA-PFLUCKER, J.C. (2007). The thymus as an inductive site for t lymphopoiesis. Annu Rev Cell Dev Biol 23: 463-493.

COHEN, T.J., WADDELL, D.S., BARRIENTOS, T., LU, Z., FENG, G., COX, G.A., BODINE, S.C. and YAO, T.P. (2007). The histone deacetylase hdac4 connects neural activity to muscle transcriptional reprogramming. J Biol Chem 282: 33752-33759.

DAVIS, F.J., GUPTA, M., CAMORETTI-MERCADO, B., SCHWARTZ, R.J. and GUPTA, M.P. (2003). Calcium/calmodulin-dependent protein kinase activates serum response factor transcription activity by its dissociation from histone deacetylase, hdac4. Implications in cardiac muscle gene regulation during hypertrophy. J Biol Chem 278: 20047-20058.

DE MARCHIS, F., RIBATTI, D., GIAMPIETRI, C., LENTINI, A., FARAONE, D., SCOCCIANTI, M., CAPOGROSSI, M.C. and FACCHIANO, A. (2002). Plateletderived growth factor inhibits basic fibroblast growth factor angiogenic properties in vitro and in vivo through its alpha receptor. Blood 99: 2045-2053.

DENG, X., EWTON, D.Z., MERCER, S.E. and FRIEDMAN, E. (2005). Mirk/dyrk1b decreases the nuclear accumulation of class ii histone deacetylases during skeletal muscle differentiation. J Biol Chem 280: 4894-4905.

DEQUIEDT, F., KASLER, H., FISCHLE, W., KIERMER, V., WEINSTEIN, M., HERNDIER, B.G. and VERDIN, E. (2003). Hdac7, a thymus-specific class ii histone deacetylase, regulates nur77 transcription and tcr-mediated apoptosis. Immunity 18: 687-698.

DEQUIEDT, F., MARTIN, M., VON BLUME, J., VERTOMMEN, D., LECOMTE, E., MARI, N., HEINEN, M.-F., BACHMANN, M., TWIZERE, J.-C., HUANG, M.C. et al. (2006). New role for hpar-1 kinases emk and c-tak1 in regulating localization and activity of class iia histone deacetylases. Mol Cell Biol 26: 7086-7102.

DEQUIEDT, F., VAN LINT, J., LECOMTE, E., VAN DUPPEN, V., SEUFFERLEIN, T., VANDENHEEDE, J.R., WATTIEZ, R. and KETTMANN, R. (2005). Phosphorylation of histone deacetylase 7 by protein kinase $d$ mediates $t$ cell receptorinduced nur77 expression and apoptosis. J Exp Med 201: 793-804.

DRESSEL, U., BAILEY, P.J., WANG, S.C., DOWNES, M., EVANS, R.M. and MUSCAT, G.E. (2001). A dynamic role for hdac7 in mef2-mediated muscle differentiation. J Biol Chem 276: 17007-11703.

FIELITZ, J., KIM, M.S., SHELTON, J.M., QI, X., HILL, J.A., RICHARDSON, J.A., BASSEL-DUBY, R. and OLSON, E.N. (2008). Requirement of protein kinase d1 for pathological cardiac remodeling. Proc Natl Acad Sci USA 105: 3059-3063.

FISCHER, D.D., CAI, R., BHATIA, U., ASSELBERGS, F.A.M., SONG, C., TERRY, R., TROGANI, N., WIDMER, R., ATADJA, P. and COHEN, D. (2002). Isolation and characterization of a novel class ii histone deacetylase, hdac10. $J$ Biol Chem 277: 6656-6666.

FISCHLE, W., DEQUIEDT, F., FILLION, M., HENDZEL, M.J., VOELTER, W. and VERDIN, E. (2001). Human hdac7 histone deacetylase activity is associated with hdac3 in vivo. J Biol Chem 276: 35826-35835.

FISCHLE, W., DEQUIEDT, F., HENDZEL, M.J., GUENTHER, M.G., LAZAR, M.A., VOELTER, W. and VERDIN, E. (2002). Enzymatic activity associated with class 
ii hdacs is dependent on a multiprotein complex containing hdac3 and smrt/ncor. Mol Cell 9: 45-57.

FISCHLE, W., EMILIANI, S., HENDZEL, M.J., NAGASE, T., NOMURA, N., VOELTER, W. and VERDIN, E. (1999). A new family of human histone deacetylases related to saccharomyces cerevisiae hda1p. J Biol Chem 274: 11713-11720.

GAO, C., LI, X., LAM, M., LIU, Y., CHAKRABORTY, S. and KAO, H.Y. (2006). Crm1 mediates nuclear export of hdac7 independently of hdac7 phosphorylation and association with 14-3-3s. FEBS Lett 580: 5096-5104.

GREGOIRE, S., TREMBLAY, A.M., XIAO, L., YANG, Q., MA, K., NIE, J., MAO, Z., WU, Z., GIGUERE, V. and YANG, X.J. (2006). Control of mef2 transcriptional activity by coordinated phosphorylation and sumoylation. $J$ Biol Chem 281 : 4423-4433.

GREGOIRE, S. and YANG, X.-J. (2005). Association with class iia histone deacetylases upregulates the sumoylation of mef2 transcription factors. $\mathrm{Mol}$ Cell Biol 25: 2273-2287.

GREGORETTI, I.V., LEE, Y.M. and GOODSON, H.V. (2004). Molecular evolution of the histone deacetylase family: Functional implications of phylogenetic analysis. J Mol Biol 338: 17-31.

GROZINGER, C.M., HASSIG, C.A. and SCHREIBER, S.L. (1999). Three proteins define a class of human histone deacetylases related to yeast hda1p. Proc Natl Acad Sci USA 96: 4868-4873.

GROZINGER, C.M. and SCHREIBER, S.L. (2000). Regulation of histone deacetylase 4 and 5 and transcriptional activity by 14-3-3-dependent cellular localization. Proc Natl Acad Sci USA 97: 7835-7840.

GUARDIOLA, A.R. and YAO, T.-P. (2002). Molecular cloning and characterization of a novel histone deacetylase hdac10. J Biol Chem 277: 3350-3356.

HA, C.H., WANG, W., JHUN, B.S., WONG, C., HAUSSER, A., PFIZENMAIER, K., MCKINSEY, T.A., OLSON, E.N. and JIN, Z.G. (2008). Protein kinase ddependent phosphorylation and nuclear export of histone deacetylase 5 mediates vascular endothelial growth factor-induced gene expression and angiogenesis. J Biol Chem 283: 14590-14599.

HABERLAND, M., ARNOLD, M.A., MCANALLY, J., PHAN, D., KIM, Y. and OLSON, E.N. (2007). Regulation of hdac9 gene expression by mef2 establishes a negative-feedback loop in the transcriptional circuitry of muscle differentiation. Mol Cell Biol 27: 518-525.

HAIGIS, M.C. and GUARENTE, L.P. (2006). Mammalian sirtuins emerging roles in physiology, aging, and calorie restriction. Genes Dev 20: 2913-21.

HAN, S., LU, J., ZHANG, Y., CHENG, C., HAN, L., WANG, X., LI, L., LIU, C. and HUANG, B. (2006). Recruitment of histone deacetylase 4 by transcription factors represses interleukin-5 transcription. Biochem J 400: 439-448.

HARRISON, B.C., KIM, M.S., VAN ROOIJ, E., PLATO, C.F., PAPST, P.J., VEGA, R.B., MCANALLY, J.A., RICHARDSON, J.A., BASSEL-DUBY, R., OLSON, E.N. et al. (2006). Regulation of cardiac stress signaling by protein kinase d1. Mol Cell Biol 26: 3875-3888.

HASSIG, C.A., TONG, J.K., FLEISCHER, T.C., OWA, T., GRABLE, P.G., AYER, D.E. and SCHREIBER, S.L. (1998). A role for histone deacetylase activity in hdac1-mediated transcriptional repression. Proc Natl Acad Sci USA 95: 35193524.

HILL, J.A. and OLSON, E.N. (2008). Cardiac plasticity. N Engl J Med 358: 13701380.

HINITS, Y. and HUGHES, S.M. (2007). Mef2s are required for thick filament formation in nascent muscle fibres. Development 134: 2511-2519.

HOLDERFIELD, M.T. and HUGHES, C.C. (2008). Crosstalk between vascular endothelial growth factor, notch, and transforming growth factor-beta in vascular morphogenesis. Circ Res 102: 637-652.

HOOK, S.S., ORIAN, A., COWLEY, S.M. and EISENMAN, R.N. (2002). Histone deacetylase 6 binds polyubiquitin through its zinc finger (paz domain) and copurifies with deubiquitinating enzymes. Proc Natl Acad Sci USA 99: 1342513430.

HOSHINO, M., TAGAWA, K., OKUDA, T., MURATA, M., OYANAGI, K., ARAI, N., MIZUTANI, T., KANAZAWA, I., WANKER, E.E. and OKAZAWA, H. (2003). Histone deacetylase activity is retained in primary neurons expressing mutant huntingtin protein. $J$ Neurochem $87:$ 257-267.

HU, E., CHEN, Z., FREDRICKSON, T., ZHU, Y., KIRKPATRICK, R., ZHANG, G.F., JOHANSON, K., SUNG, C.-M., LIU, R. and WINKLER, J. (2000). Cloning and characterization of a novel human class i histone deacetylase that functions as a transcription repressor. J Biol Chem 275: 15254-15264.

IGA, J., UENO, S., YAMAUCHI, K., NUMATA, S., KINOUCHI, S., TAYOSHISHIBUYA, S., SONG, H. and OHMORI, T. (2007). Altered hdac5 and creb mrna expressions in the peripheral leukocytes of major depression. Prog Neuropsychopharmacol Biol Psychiatry 31: 628-632.

ILli, B., DEllo Russo, C., COlussi, C., ROSATI, J., PAllaORO, M., SPALLOTTA, F., ROTILI, D., VALENTE, S., RAGONE, G., MARTELLI, F. et al. (2008). Nitric oxide modulates chromatin folding in human endothelial cells via protein phosphatase $2 \mathrm{a}$ activation and class ii histone deacetylases nuclear shuttling. Circ Res 102: 51-58.

JENSEN, E.D., SCHROEDER, T.M., BAILEY, J., GOPALAKRISHNAN, R. and WESTENDORF, J.J. (2008). Histone deacetylase 7 associates with runx2 and represses its activity during osteoblast maturation in a deacetylation-independent manner. J Bone Miner Res 23: 361-372.

JEON, E.J., LEE, K.Y., CHOI, N.S., LEE, M.H., KIM, H.N., JIN, Y.H., RYOO, H.M., CHOI, J.Y., YOSHIDA, M., NISHINO, N. et al. (2006). Bone morphogenetic protein-2 stimulates runx2 acetylation. J Biol Chem 281: 16502-16511.

JIN, Y.H., JEON, E.J., LI, Q.L., LEE, Y.H., CHOI, J.K., KIM, W.J., LEE, K.Y. and BAE, S.C. (2004). Transforming growth factor-beta stimulates p300-dependent runx3 acetylation, which inhibits ubiquitination-mediated degradation. J Biol Chem 279: 29409-29417.

KANG, J.S., ALLISTON, T., DELSTON, R. and DERYNCK, R. (2005). Repression of runx2 function by tgf-beta through recruitment of class ii histone deacetylases by smad3. Embo J 24: 2543-2555.

KAO, H.-Y., DOWNES, M., ORDENTLICH, P. and EVANS, R.M. (2000). Isolation of a novel histone deacetylase reveals that class $\mathrm{i}$ and class ii deacetylases promote smrt-mediated repression. Genes Dev 14: 55-66.

KAO, H.-Y., VERDEL, A., TSAI, C.-C., SIMON, C., JUGUILON, H. and KHOCHBIN, S. (2001). Mechanism for nucleocytoplasmic shuttling of histone deacetylase 7. J Biol Chem 276: 47496-47507.

KARAMBOULAS, C., DAKUBO, G.D., LIU, J., DE REPENTIGNY, Y., YUTZEY, K. WALLACE, V.A., KOTHARY, R. and SKERJANC, I.S. (2006a). Disruption of mef2 activity in cardiomyoblasts inhibits cardiomyogenesis. J Cell Sci 119: 4315-4321.

KARAMBOULAS, C., SWEDANI, A., WARD, C., AL-MADHOUN, A.S., WILTON, S., BOISVENUE, S., RIDGEWAY, A.G. and SKERJANC, I.S. (2006b). Hdac activity regulates entry of mesoderm cells into the cardiac muscle lineage. J Cell Sci 119: 4305-4314.

KASLER, H.G. and VERDIN, E. (2007). Histone deacetylase 7 functions as a key regulator of genes involved in both positive and negative selection of thymocytes. J Biol Chem 27: 5184-5200.

KIM, M.S., FIELITZ, J., MCANALLY, J., SHELTON, J.M., LEMON, D.D., MCKINSEY, T.A., RICHARDSON, J.A., BASSEL-DUBY, R. and OLSON, E.N. (2008a). Protein kinase d1 stimulates mef2 activity in skeletal muscle and enhances muscle performance. Mol Cell Biol 28: 3600-3609.

KIM, M.S., KWON, H.J., LEE, Y.M., BAEK, J.H., JANG, J.E., LEE, S.W., MOON, E.J., KIM, H.S., LEE, S.K., CHUNG, H.Y. et al. (2001). Histone deacetylases induce angiogenesis by negative regulation of tumor suppressor genes. Nat Med 7: 437-443

KIM, Y., PHAN, D., VAN ROOIJ, E., WANG, D.Z., MCANALLY, J., QI, X., RICHARDSON, J.A., HILL, J.A., BASSEL-DUBY, R. and OLSON, E.N. (2008b). The mef2d transcription factor mediates stress-dependent cardiac remodeling in mice. J Clin Invest 118: 124-132.

KIRSH, O., SEELER, J.S., PICHLER, A., GAST, A., MULLER, S., MISKA, E. MATHIEU, M., HAREL-BELLAN, A., KOUZARIDES, T., MELCHIOR, F. et al. (2002). The sumo e3 ligase ranbp2 promotes modification of the hdac4 deacetylase. Embo J 21: 2682-2691.

KOMORI, T. (2008). Regulation of bone development and maintenance by runx2 Front Biosci 13: 898-903.

KOMORI, T., YAGI, H., NOMURA, S., YAMAGUCHI, A., SASAKI, K., DEGUCHI, K. SHIMIZU, Y., BRONSON, R.T., GAO, Y.H., INADA, M. et al. (1997). Targeted disruption of cbfa1 results in a complete lack of bone formation owing to maturational arrest of osteoblasts. Cell 89: 755-764.

KWON, H.J., KIM, M.S., KIM, M.J., NAKAJIMA, H. and KIM, K.W. (2002). Histone deacetylase inhibitor fk228 inhibits tumor angiogenesis. Int J Cancer 97: 290- 
296.

LAHM A., PAOLINI C., PALLAORO M., NARDI M.C. JONES P., NEDDERMANNP., SAMBUCINI S., BOTTOMLEY M.J., LO SURDO P., CARFI A., KOCH U., DE FRANCESCO R., STEINKÜHLER C. and GALLINARI P. (2008). Unraveling the hidden catalytic activity of vertebrate class Ila histone deacetylases. Proc Natl Acad Sci USA.104: 17335-40.

LEMERCIER, C., VERDEL, A., GALLOO, B., CURTET, S., BROCARD, M.P. and KHOCHBIN, S. (2000). Mhda1/hdac5 histone deacetylase interacts with and represses mef2a transcriptional activity. J Biol Chem 275: 15594-15599.

LI, X., SONG, S., LIU, Y., KO, S.H. and KAO, H.Y. (2004). Phosphorylation of the histone deacetylase 7 modulates its stability and association with 14-3-3 proteins. J Biol Chem 279: 34201-34208.

LILLY, B., ZHAO, B., RANGANAYAKULU, G., PATERSON, B.M., SCHULZ, R.A and OLSON, E.N. (1995). Requirement of mads domain transcription factor dmef2 for muscle formation in drosophila. Science 267: 688-693.

LIN, Q., LU, J., YANAGISAWA, H., WEBB, R., LYONS, G.E., RICHARDSON, J.A. and OLSON, E.N. (1998). Requirement of the mads-box transcription factor mef2c for vascular development. Development 125: 4565-4574.

LIN, Q., SCHWARZ, J., BUCANA, C. and N. OLSON, E. (1997). Control of mouse cardiac morphogenesis and myogenesis by transcription factor mef2c. Science 276: 1404-1407.

LINSEMAN, D.A., BARTLEY, C.M., LE, S.S., LAESSIG, T.A., BOUCHARD, R.J., MEINTZER, M.K., LI, M. and HEIDENREICH, K.A. (2003). Inactivation of the myocyte enhancer factor-2 repressor histone deacetylase- 5 by endogenous ca2//calmodulin-dependent kinase ii promotes depolarization-mediated cerebellar granule neuron survival. J Biol Chem 278: 41472-41481.

LIU, Y., RANDALL, W.R. and SCHNEIDER, M.F. (2005). Activity-dependent and independent nuclear fluxes of hdac4 mediated by different kinases in adult skeletal muscle. J Cell Biol 168: 887-897.

LIZCANO, J.M., GORANSSON, O., TOTH, R., DEAK, M., MORRICE, N.A., BOUDEAU, J., HAWLEY, S.A., UDD, L., MAKELA, T.P., HARDIE, D.G. et al. (2004). Lkb1 is a master kinase that activates 13 kinases of the ampk subfamily, including mark/par-1. Embo J 23: 833-843.

LONG, X., CREEMERS, E.E., WANG, D.Z., OLSON, E.N. and MIANO, J.M. (2007). Myocardin is a bifunctional switch for smooth versus skeletal muscle differentiation. Proc Natl Acad Sci USA 104: 16570-16575.

LU, J., MCKINSEY, T.A., NICOL, R.L. and OLSON, E.N. (2000a). Signal-dependent activation of the mef2 transcription factor by dissociation from histone deacetylases. Proc Natl Acad Sci USA 97: 4070-4075.

LU, J., MCKINSEY, T.A., ZHANG, C.L. and OLSON, E.N. (2000b). Regulation of skeletal myogenesis by association of the mef2 transcription factor with class ii histone deacetylases. Mol Cell 6: 233-244.

MAJDZADEH, N., MORRISON, B.E. and D'MELLO, S.R. (2008). Class iia hdacs in the regulation of neurodegeneration. Front Biosci 13: 1072-1082.

MAO, Z., BONNI, A., XIA, F., NADAL-VICENS, M. and GREENBERG, M.E. (1999). Neuronal activity-dependent cell survival mediated by transcription factor mef2. Science 286: 785-790.

MARTIN, M., KETTMANN, R. and DEQUIEDT, F. (2007). Class iia histone deacetylases: Regulating the regulators. Oncogene 26: 5450-5467.

MARTIN, M., POTENTE, M., JANSSENS, V., VERTOMMEN, D., TWIZERE, J.C., RIDER, M.H., GORIS, J., DIMMELER, S., KETTMANN, R. and DEQUIEDT, F. (2008). Protein phosphatase 2a controls the activity of histone deacetylase 7 during t cell apoptosis and angiogenesis. Proc Natl Acad Sci USA 105: 47274732 .

MATTHEWS, S.A., LIU, P., SPITALER, M., OLSON, E.N., MCKINSEY, T.A., CANTRELL, D.A. and SCHARENBERG, A.M. (2006). Essential role for protein kinase $d$ family kinases in the regulation of class ii histone deacetylases in $b$ lymphocytes. Mol Cell Biol 26: 1569-1577.

MCKINSEY, T.A., ZHANG, C.L., LU, J. and OLSON, E.N. (2000a). Signal-dependent nuclear export of a histone deacetylase regulates muscle differentiation. Nature 408: 106-111.

MCKINSEY, T.A., ZHANG, C.L. and OLSON, E.N. (2000b). Activation of the myocyte enhancer factor-2 transcription factor by calcium/calmodulin-dependent protein kinase-stimulated binding of 14-3-3 to histone deacetylase 5. Proc Natl Acad Sci USA 97: 14400-14405.

MCKINSEY, T.A., ZHANG, C.L. and OLSON, E.N. (2001). Identification of a signal- responsive nuclear export sequence in class ii histone deacetylases. Mol Cell Biol 21: 6312-6321.

MCKINSEY, T.A., ZHANG, C.L. and OLSON, E.N. (2002). Signaling chromatin to make muscle. Curr Opin Cell Biol 14: 763-772.

MEJAT, A., RAMOND, F., BASSEL-DUBY, R., KHOCHBIN, S., OLSON, E.N. and SCHAEFFER, L. (2005). Histone deacetylase 9 couples neuronal activity to muscle chromatin acetylation and gene expression. Nat Neurosci 8: 313-21.

MISKA, E.A., KARLSSON, C., LANGLEY, E., NIELSEN, S.J., PINES, J. and KOUZARIDES, T. (1999). Hdac4 deacetylase associates with and represses the mef2 transcription factor. Embo J 18: 5099-5107.

MISKA, E.A., LANGLEY, E., WOLF, D., KARLSSON, C., PINES, J. and KOUZARIDES, T. (2001). Differential localization of hdac4 orchestrates muscle differentiation. Nucleic Acids Res 29: 3439-3447.

MOTTET, D., BELLAHCENE, A., PIROTTE, S., WALTREGNY, D., DEROANNE, C., LAMOUR, V., LIDEREAU, R. and CASTRONOVO, V. (2007). Histone deacetylase 7 silencing alters endothelial cell migration, a key step in angiogenesis. Circ Res 101: 1237-1246.

MUSLIN, A.J. and XING, H. (2000). 14-3-3 proteins: Regulation of subcellular localization by molecular interference. Cell Signal 12: 703-709.

NADRUZ, W., JR., KOBARG, C.B., CONSTANCIO, S.S., CORAT, P.D.C. and FRANCHINI, K.G. (2003). Load-induced transcriptional activation of c-jun in rat myocardium: Regulation by myocyte enhancer factor 2. Circ Res 92: 243-251.

OTTO, F., THORNELL, A.P., CROMPTON, T., DENZEL, A., GILMOUR, K.C., ROSEWELL, I.R., STAMP, G.W., BEDDINGTON, R.S., MUNDLOS, S., OLSEN, B.R. et al. (1997). Cbfa1, a candidate gene for cleidocranial dysplasia syndrome, is essential for osteoblast differentiation and bone development. Cell89: 765-771.

OUAISSI, M., SIELEZNEFF, I., SILVESTRE, R., SASTRE, B., BERNARD, J.P., LAFONTAINE, J.S., PAYAN, M.J., DAHAN, L., PIRRO, N., SEITZ, J.F. et al. (2008). High histone deacetylase 7 (hdac7) expression is significantly associated with adenocarcinomas of the pancreas. Ann Surg Oncol. 15: 2318-2328.

OZDAG, H., TESCHENDORFF, A.E., AHMED, A.A., HYLAND, S.J., BLENKIRON, C., BOBROW, L., VEERAKUMARASIVAM, A., BURTT, G., SUBKHANKULOVA, T., ARENDS, M.J. et al. (2006). Differential expression of selected histone modifier genes in human solid cancers. BMC Genomics 7: 90.

PARONI, G., CERNOTTA, N., DELLO RUSSO, C., GALLINARI, P., PALLAORO, M., FOTI, C., TALAMO, F., ORSATTI, L., STEINKUHLER, C. and BRANCOLINI, C. (2008). Pp2a regulates hdac4 nuclear import. Mol Biol Cell 19: 655-667.

PARONI, G., MIZZAU, M., HENDERSON, C., DEL SAL, G., SCHNEIDER, C. and BRANCOLINI, C. (2004). Caspase-dependent regulation of histone deacetylase 4 nuclear-cytoplasmic shuttling promotes apoptosis. Mol Biol Cell 15: 28042818.

PARRA, M., KASLER, H., MCKINSEY, T.A., OLSON, E.N. and VERDIN, E. (2005). Protein kinase d1 phosphorylates hdac7 and induces its nuclear export after tcell receptor activation. J Biol Chem 280: 13762-13770.

PARRA, M., MAHMOUDI, T. and VERDIN, E. (2007). Myosin phosphatase dephosphorylates hdac7, controls its nucleocytoplasmic shuttling, and inhibits apoptosis in thymocytes. Genes Dev 21: 638-643.

PETRIE, K., GUIDEZ, F., HOWELL, L., HEALY, L., WAXMAN, S., GREAVES, M. and ZELENT, A. (2003). The histone deacetylase 9 gene encodes multiple protein isoforms. J Biol Chem 278: 16059-16072.

POTTHOFF, M.J., WU, H., ARNOLD, M.A., SHELTON, J.M., BACKS, J., MCANALLY, J., RICHARDSON, J.A., BASSEL-DUBY, R. and OLSON, E.N. (2007). Histone deacetylase degradation and mef2 activation promote the formation of slow-twitch myofibers. J Clin Invest 117: 2459-2467.

RANGANAYAKULU, G., ZHAO, B., DOKIDIS, A., MOLKENTIN, J.D., OLSON, E.N. and SCHULZ, R.A. (1995). A series of mutations in the d-mef2 transcription factor reveal multiple functions in larval and adult myogenesis in drosophila. Dev. Biol. 171: 169-181.

RENTHAL, W., MAZE, I., KRISHNAN, V., COVINGTON, H.E., 3RD, XIAO, G., KUMAR, A., RUSSO, S.J., GRAHAM, A., TSANKOVA, N., KIPPIN, T.E. et al. (2007). Histone deacetylase 5 epigenetically controls behavioral adaptations to chronic emotional stimuli. Neuron 56: 517-529.

RUNDLETT, S.E., CARMEN, A.A., KOBAYASHI, R., BAVYKIN, S., TURNER, B.M. and GRUNSTEIN, M. (1996). Hda1 and rpd3 are members of distinct yeast histone deacetylase complexes that regulate silencing and transcription. Proc 
Natl Acad Sci USA 93: 14503-14508.

SCOTT, F.L., FUCHS, G.J., BOYD, S.E., DENAULT, J.B., HAWKINS, C.J., DEQUIEDT, F. and SALVESEN, G.S. (2008). Caspase-8 cleaves histone deacetylase 7 and abolishes its transcription repressor function. $J$ Biol Chem. 283: 19499-19510.

SHALIZI, A., GAUDILLIERE, B., YUAN, Z., STEGMULLER, J., SHIROGANE, T., GE, Q., TAN, Y., SCHULMAN, B., HARPER, J.W. and BONNI, A. (2006). A calcium-regulated mef2 sumoylation switch controls postsynaptic differentiation. Science 311: 1012-1017.

SHALIZI, A.K. and BONNI, A. (2005). Brawn for brains: The role of mef2 proteins in the developing nervous system. Curr Top Dev Biol 69: 239-266.

SONG, K., BACKS, J., MCANALLY, J., QI, X., GERARD, R.D., RICHARDSON, J.A., HILL, J.A., BASSEL-DUBY, R. and OLSON, E.N. (2006). The transcriptional coactivator camta2 stimulates cardiac growth by opposing class ii histone deacetylases. Cell 125: 453-466.

SPARROW, D.B., MISKA, E.A., LANGLEY, E., REYNAUD-DEONAUTH, S., KOTECHA, S., TOWERS, N., SPOHR, G., KOUZARIDES, T. and MOHUN, T.J. (1999). Mef-2 function is modified by a novel co-repressor, mitr. Embo $J 18$ : 5085-5098.

SUCHAROV, C.C., LANGER, S., BRISTOW, M. and LEINWAND, L. (2006). Shuttling of hdac5 in h9c2 cells regulates yy 1 function through camkiv/pkd and pp2a. Am J Physiol Cell Physiol 291: C1029-C1037.

TAKEDA, S., BONNAMY, J.P., OWEN, M.J., DUCY, P. and KARSENTY, G. (2001). Continuous expression of cbfa1 in nonhypertrophic chondrocytes uncovers its ability to induce hypertrophic chondrocyte differentiation and partially rescues cbfa1-deficient mice. Genes Dev 15: 467-481.

TAKEMORI, H., KATOH HASHIMOTO Y., NAKAE J., OLSON E.N. and OKAMOTO M. (2009). Inactivation of HDAC5 by SIK1 in AICAR-treated C2C12 Myoblast. Endocr. J. 56: 121-130.

TANG, H. and GOLDMAN, D. (2006). Activity-dependent gene regulation in skeletal muscle is mediated by a histone deacetylase (hdac)-dach2-myogenin signal transduction cascade. Proc Natl Acad Sci USA 103: 16977-16982.

TATHAM, M.H., JAFFRAY, E., VAUGHAN, O.A., DESTERRO, J.M., BOTTING, C.H., NAISMITH, J.H. and HAY, R.T. (2001). Polymeric chains of sumo-2 and sumo-3 are conjugated to protein substrates by sae1/sae2 and ubc9. J Biol Chem 276: 35368-35374.

TAUNTON, J., HASSIG, C.A. and SCHREIBER, S.L. (1996). A mammalian histone deacetylase related to the yeast transcriptional regulator rpd3p. Science 272 : 408-411.

TONG, J.J., LIU, J., BERTOS, N.R. and YANG, X.-J. (2002). Identification of hdac10, a novel class ii human histone deacetylase containing a leucine-rich domain. Nucleic Acids Res 30: 1114-1123.

TUDDENHAM, L., WHEELER, G., NTOUNIA-FOUSARA, S., WATERS, J., HAJIHOSSEINI, M.K., CLARK, I. and DALMAY, T. (2006). The cartilage specific microrna-140 targets histone deacetylase 4 in mouse cells. FEBS Lett 580: 4214-4217.

UETA, C., IWAMOTO, M., KANATANI, N., YOSHIDA, C., LIU, Y., ENOMOTOIWAMOTO, M., OHMORI, T., ENOMOTO, H., NAKATA, K., TAKADA, K. et al. (2001). Skeletal malformations caused by overexpression of cbfa1 or its dominant negative form in chondrocytes. J Cell Biol 153: 87-100.

VEGA, R.B., HARRISON, B.C., MEADOWS, E., ROBERTS, C.R., PAPST, P.J., OLSON, E.N. and MCKINSEY, T.A. (2004a). Protein kinases $\mathrm{c}$ and d mediate agonist-dependent cardiac hypertrophy through nuclear export of histone deacetylase 5. Mol Cell Biol 24: 8374-8385.

VEGA, R.B., MATSUDA, K., OH, J., BARBOSA, A.C., YANG, X., MEADOWS, E., MCANALLY, J., POMAJZL, C., SHELTON, J.M., RICHARDSON, J.A. et al. (2004b). Histone deacetylase 4 controls chondrocyte hypertrophy during skeletogenesis. Cell 119: 555-566.
VERDEL, A. and KHOCHBIN, S. (1999). Identification of a new family of higher eukaryotic histone deacetylases. Coordinate expression of differentiationdependent chromatin modifiers. J Biol Chem 274: 2440-2445.

VERDIN, E., DEQUIEDT, F. and KASLER, H.G. (2003). Class ii histone deacetylases: Versatile regulators. Trends Genet 19: 286-293.

VERZI, M.P., AGARWAL, P., BROWN, C., MCCULLEY, D.J., SCHWARZ, J.J. and BLACK, B.L. (2007). The transcription factor mef2c is required for craniofacial development. Dev Cell 12: 645-652.

WANG, A.H., BERTOS, N.R., VeZMAR, M., PELletier, N., CROSATO, M., HENG, H.H., TH'NG, J., HAN, J. and YANG, X.-J. (1999). Hdac4, a human histone deacetylase related to yeast hda1, is a transcriptional corepressor. Mol Cell Biol 19: 7816-7827.

WANG, A.H., KRUHLAK, M.J., WU, J., BERTOS, N.R., VEZMAR, M., POSNER, B.I., BAZETT-JONES, D.P. and YANG, X.-J. (2000). Regulation of histone deacetylase 4 by binding of 14-3-3 proteins. Mol Cell Biol 20: 6904-6912.

WANG, A.H. and YANG, X.J. (2001). Histone deacetylase 4 possesses intrinsic nuclear import and export signals. Mol Cell Biol 21: 5992-6005.

WANG, S., LI, X., PARRA, M., VERDIN, E., BASSEL-DUBY, R. and OLSON, E.N. (2008). Control of endothelial cell proliferation and migration by vegf signaling to histone deacetylase 7. Proc Natl Acad Sci USA 105: 7738-7743.

WU, H., KANATOUS, S.B., THURMOND, F.A., GALLARDO, T., ISOTANI, E., BASSEL-DUBY, R. and WILLIAMS, R.S. (2002). Regulation of mitochondrial biogenesis in skeletal muscle by camk. Science 296: 349-352.

WU, H., NAYA, F.J., MCKINSEY, T.A., MERCER, B., SHELTON, J.M., CHIN, E.R., SIMARD, A.R., MICHEL, R.N., BASSEL-DUBY, R., OLSON, E.N. et al. (2000). Mef2 responds to multiple calcium-regulated signals in the control of skeletal muscle fiber type. Embo J 19: 1963-1973.

YANG, X.J. and SETO, E. (2008). The rpd3/hda1 family of lysine deacetylases: From bacteria and yeast to mice and men. Nat Rev Mol Cell Biol 9: 206-218.

YUKI, Y., IMOTO, I., IMAIZUMI, M., HIBI, S., KANEKO, Y., AMAGASA, T. and INAZAWA, J. (2004). Identification of a novel fusion gene in a pre-b acute lymphoblastic leukemia with $\mathrm{t}(1 ; 19)$ (q23;p13). Cancer Sci 95: 503-507.

ZAFFRAN, S. and FRASCH, M. (2002). Early signals in cardiac development. Circ Res 91: 457-69.

ZHANG, C.L., MCKINSEY, T.A., CHANG, S., ANTOS, C.L., HILL, J.A. and OLSON, E.N. (2002). Class ii histone deacetylases act as signal-responsive repressors of cardiac hypertrophy. Cell 110: 479-488.

ZHANG, C.L., MCKINSEY, T.A., LU, J.-R. and OLSON, E.N. (2001a). Association of cooh-terminal-binding protein (ctbp) and mef2-interacting transcription repressor (mitr) contributes to transcriptional repression of the mef2 transcription factor. J Biol Chem 276: 35-39.

ZHANG, C.L., MCKINSEY, T.A. and OLSON, E.N. (2001b). The transcriptional corepressor mitr is a signal-responsive inhibitor of myogenesis. Proc Natl Acad Sci USA 98: 7354-7359.

ZHAO, X., STERNSDORF, T., BOLGER, T.A., EVANS, R.M. and YAO, T.-P. (2005). Regulation of mef2 by histone deacetylase 4- and sirt1 deacetylasemediated lysine modifications. Mol Cell Biol 25: 8456-8464.

ZHOU, X., MARKS, P.A., RIFKIND, R.A. and RICHON, V.M. (2001). Cloning and characterization of a histone deacetylase, hdac9. Proc Natl Acad Sci USA 98: 10572-10577.

ZHOU, X., RICHON, V.M., RIFKIND, R.A. and MARKS, P.A. (2000a). Identification of a transcriptional repressor related to the noncatalytic domain of histone deacetylases 4 and 5. Proc Natl Acad Sci USA 97: 1056-1061.

ZHOU, X., RICHON, V.M., WANG, A.H., YANG, X.J., RIFKIND, R.A. and MARKS, P.A. (2000b). Histone deacetylase 4 associates with extracellular signalregulated kinases 1 and 2 , and its cellular localization is regulated by oncogenic ras. Proc Natl Acad Sci USA 97: 14329-14333. 


\section{Further Related Reading, published previously in the Int. J. Dev. Biol.}

See our Special Issue Fertilization edited by Paul M. Wassarman and Victor D. Vacquier at: http://www.ijdb.ehu.es/web/contents.php?vol=52\&issue=5-6

The Xenopus Bowline/Ripply family proteins negatively regulate the transcriptional activity of T-box transcription factors Keisuke Hitachi, Hiroki Danno, Shunsuke Tazumi, Yuko Aihara, Hideho Uchiyama, Koji Okabayashi, Akiko Kondow and Makoto Asashima Int. J. Dev. Biol. (2009) 52: 2823-2823

Dynamic alterations of linker histone variants during development James S. Godde and Kiyoe Ura

Int. J. Dev. Biol. (2009) 52: 2644-2644

Chromatin remodeling in plant development José A. Jarillo, Manuel Piñeiro, Pilar Cubas and José M. Martínez-Zapater Int. J. Dev. Biol. (2009) 52: 2460-2460

A histone $\mathrm{H} 1$ variant is required for erythrocyte maturation in medaka Osamu Matsuoka, Norihisa Shindo, Daisuke Arai and Toru Higashinakagawa Int. J. Dev. Biol. (2008) 52: 887-892

Hypomethylation of paternal DNA in the late mouse zygote is not essential for development Zbigniew Polanski, Nami Motosugi, Chizuko Tsurumi, Takashi Hiiragi and Steffen Hoffmann Int. J. Dev. Biol. (2008) 52: 295-298

Cyclin B2/cyclin-dependent kinase1 dissociation precedes CDK1 Thr-161 dephosphorylation upon M-phase promoting factor inactivation in Xenopus laevis cell-free extract

Franck Chesnel, Franck Bazile, Aude Pascal and Jacek Z. Kubiak

Int. J. Dev. Biol. (2007) 51: 297-305

Dynamic distribution of the replacement histone variant $\mathrm{H} 3.3$ in the mouse oocyte and preimplantation embryos

Maria-Elena Torres-Padilla, Andrew J. Bannister, Paul J. Hurd, Tony Kouzarides and Magdalena Zernicka-Goetz

Int. J. Dev. Biol. (2006) 50: 455-461

Developmental expression of the High Mobility Group B gene in the amphioxus, Branchiostoma belcheri tsingtauense

Xiangwei Huang, Lifeng Wang and Hongwei Zhang

Int. J. Dev. Biol. (2005) 49: 49-46

Histone methylation defines epigenetic asymmetry in the mouse zygote. Katharine L Arney, Siqin Bao, Andrew J Bannister, Tony Kouzarides and M Azim Surani Int. J. Dev. Biol. (2002) 46: 317-320

Multiple stage-dependent roles for histone deacetylases during amphibian embryogenesis: implications for the involvement of extracellular matrix remodeling. S Damjanovski, L M Sachs and Y B Shi

Int. J. Dev. Biol. (2000) 44: 769-776

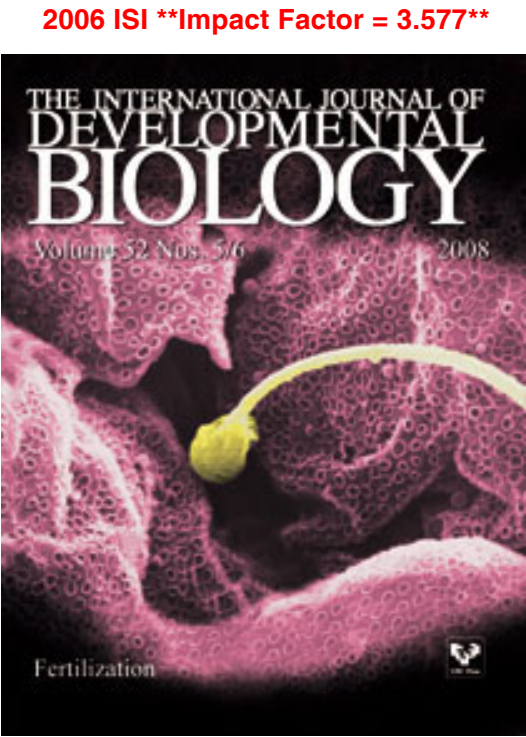

